Labor Market and Institutional Drivers of Youth Irregular Migration: Evidence from the MENA Region

GHASSAN DIBEH

ALI FAKIH

WALID MARROUCH 
2018s-34

\title{
Labor Market and Institutional Drivers of Youth Irregular Migration: Evidence from the MENA Region
}

\author{
Ghassan Dibeh, Ali Fakih, Walid Marrouch
}

\section{Série Scientifique \\ Scientific Series}

\section{Montréal \\ Octobre/October 2018}

(C) 2018 Ghassan Dibeh, Ali Fakih, Walid Marrouch. Tous droits réservés. All rights reserved. Reproduction partielle permise avec citation du document source, incluant la notice (C). Short sections may be quoted without explicit permission, if full credit, including (C) notice, is given to the source.

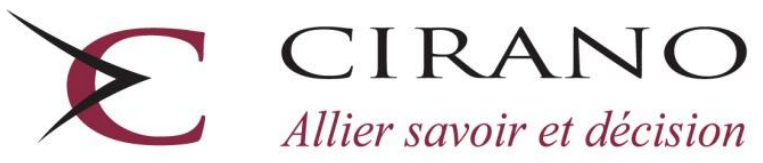

Centre interuniversitaire de recherche en analyse des organisations 


\section{CIRANO}

Le CIRANO est un organisme sans but lucratif constitué en vertu de la Loi des compagnies du Québec. Le financement de son infrastructure et de ses activités de recherche provient des cotisations de ses organisations-membres, d'une subvention d'infrastructure du gouvernement du Québec, de même que des subventions et mandats obtenus par ses équipes de recherche.

CIRANO is a private non-profit organization incorporated under the Quebec Companies Act. Its infrastructure and research activities are funded through fees paid by member organizations, an infrastructure grant from the government of Quebec, and grants and research mandates obtained by its research teams.

\section{Les partenaires du CIRANO}

\section{Partenaires corporatifs}

Autorité des marchés financiers

Banque de développement du Canada

Banque du Canada

Banque Laurentienne du Canada

Banque Nationale du Canada

Bell Canada

BMO Groupe financier

Caisse de dépôt et placement du Québec

Énergir

Hydro-Québec

Innovation, Sciences et Développement économique Canada

Intact Corporation Financière

Investissements PSP

Ministère de l'Économie, de la Science et de l'Innovation

Ministère des Finances du Québec

Mouvement Desjardins

Power Corporation du Canada

Rio Tinto

Ville de Montréal

\section{Partenaires universitaires}

École de technologie supérieure

HEC Montréal

Institut national de la recherche scientifique

Polytechnique Montréal

Université Concordia

Université de Montréal

Université de Sherbrooke

Université du Québec

Université du Québec à Montréal

Université Laval

Université McGill

Le CIRANO collabore avec de nombreux centres et chaires de recherche universitaires dont on peut consulter la liste sur son site web.

Les cahiers de la série scientifique (CS) visent à rendre accessibles des résultats de recherche effectuée au CIRANO afin de susciter échanges et commentaires. Ces cahiers sont écrits dans le style des publications scientifiques. Les idées et les opinions émises sont sous l'unique responsabilité des auteurs et ne représentent pas nécessairement les positions du CIRANO ou de ses partenaires.

This paper presents research carried out at CIRANO and aims at encouraging discussion and comment. The observations and viewpoints expressed are the sole responsibility of the authors. They do not necessarily represent positions of CIRANO or its partners.

ISSN 2292-0838 (en ligne) 


\title{
Labor Market and Institutional Drivers of Youth Irregular Migration: Evidence from the MENA Region*
}

\author{
Ghassan Dibeh ${ }^{*}$, Ali Fakih ${ }^{\star}$, Walid Marrouch ${ }^{\S}$
}

\begin{abstract}
Irregular migration became an alarming issue over the last decade for both developed and developing countries. A prevailing assumption in migration policy is that labor market and institutional characteristics play a crucial role in pushing people to leave their home countries in search for better life prospects. This paper examines this hypothesis using a unique dataset covering young people aged 15 to 29 from five major MENA countries from the year 2016. Using a probit model, the paper finds that labor market drivers (unemployment, job sector, social security, contract type) are of great importance for the decision to migrate irregularly amongst the youth in the MENA region and that the quality of institutions matters. In addition, the lack of wealth and economic opportunities enhance their willingness to engage in irregular migration.
\end{abstract}

Keywords: Irregular Migration, Youth, Labor Markets, Institutions, Arab Spring

JEL Codes: J61, O17

\footnotetext{
* Acknowledgements: The research leading to these results has received funding from the European Community's Seventh Framework Programme FP7/2007-2013 under grant agreement $\mathrm{n}^{\circ} 613174$ for the SAHWA Project (www.sahwa.eu). The authors are grateful for valuable comments from participants at the symposium on 'Migration and Work' at the 5th Conference of the Regulating for Decent Work Network organized by the ILO, Geneva, 3-5 July, 2017. The authors thank Mohammad Hammoud for excellent research assistance.

${ }^{\dagger}$ Lebanese American University

$\$$ Corresponding author

Lebanese American University, IZA, CIRANO, ERF, and GLO

Department of Economics, Lebanese American University, P.O. Box: 13-5053 Chouran, Beirut 1102 2801, Lebanon; Phone: +961-1 7864 56, Fax: + 961-1 8670 98, E-mail address: afakih@lau.edu.lb

$\S$ Lebanese American University and CIRANO
} 


\section{Introduction}

According to the International Organization of Migration (IOM), irregular migration is defined as the "movement [of people] that takes place outside the regulatory norms of the sending, transit and receiving countries". ${ }^{1}$ Such irregular (or illegal) migration has become an increasingly contentious global political issue against the backdrop of an increase in the global flow of refugees and the rise of anti-immigration populist movements in the western hemisphere. A particular irregular migration flow, that has increased tremendously in recent years, is the flow of refugees from Middle East and North Africa (MENA) to Europe subsequent to the onset of the political upheavals that unraveled in the aftermath of the 'Arab Spring' in 2011.

For instance, prior to 2011, Europe received around 500,000 irregular migrants every year where a substantial part of these flows came from the MENA region (Mehdi and Fares, 2004). This number reached close to a million in 2015 (Mangin and Zenou, 2016). For the period 2009-2015, $38 \%$ of those who attempted to migrate irregularly to Europe were Syrians making them the largest single group engaged in irregular crossing into Europe (Dustmann et al., 2016). According to the UNHCR, between 2011 and 2014, irregular migrants crossing the Mediterranean from the MENA region into Europe, increased by around 40\%. De Bruycker et al. (2013) also show that irregular migrants from Egypt, Algeria, Tunisia, and Syria are among the top ten countries which dominated international migration flows to Europe over the period 20082012.

In addition, MENA countries themselves are receivers of irregular migrants from Sub-Saharan Africa and from other parts of Asia mostly as a transient migrants on their way to the European continent. Thus, the MENA region is today a staging zone for increased irregular migration activity on both the receiving and sending ends (Fargues, 2009). ${ }^{2}$ These flows have been associated with a high human death toll and extreme hardships amongst the migrants when crossing the Mediterranean (Hammond, 2015).

\footnotetext{
${ }^{1}$ https://www.iom.int/key-migration-terms

2 Unlike regular migration, we observe that most irregular migratory flows are directed towards geographically proximate regions. For instance, most irregular flows into the United States are from Latin America, while those coming into Europe are from the MENA and Sub-Saharan Africa (Dustmann et al., 2016; Orrenius and Zavodny, 2016). This difference is attributed to the difficulty of crossing oceans or continents without proper documentation.
} 
In addition to the upsurge in irregular flows resulting from political and security shocks, irregular migration can be driven by labor market and institutional factors. In this respect, migration is considered as a form of labor mobility engendered by labor market 'push' drivers and economic institutional, and industrial factors (De Haas, 2008; Koser and McAuliffe, 2013; Loschmann et al., 2014; Mbaye, 2014). However, extant studies have overlooked some important factors driving people to illegally migrate (e.g. Ryo, 2013; Buehn and Eichler, 2013; Browne, 2015) and

have rarely considered the case of the youth population in home countries. Even though the study of labor migration is well developed in the literature (e.g. Amuedo-Dorantes and De la Rica, 2007; Andall, 2007), we observe scant evidence on factors pushing people to take the path of irregular migration in such studies.

In this paper, we contribute to both labor and industrial relations literatures by investigating the case of 'irregular labor migration' amongst the youth from the MENA region, a region that has witnessed recently a series of upheavals and civil strife in the aftermath of the Arab Spring. In this respect, it provides an empirical 'window' into the determinants of such flows for an increasingly important segment of global irregular migration. Specifically, the paper focuses on the role played by the labor market, economic constraints related to wealth, and institutional factors in increasing the probability of irregular youth migration coming out from the MENA region. An empirical analysis is carried out using a discrete choice model that captures the likelihood to migrate irregularly from the region using a unique dataset on the youth covering five major MENA countries for the year 2016.

The rest of the paper is organized as follows. In section 2, we overview the drivers of irregular migration and the various hypotheses proposed in the related literature. In section 3, we discuss the methodology and data used in our analysis. In section 4, we present the results. In Section 5, we provide a discussion. Finally, in section 6, we make some concluding remarks.

\section{The drivers of irregular migration}

Governments and scholars are recently paying a great deal of attention at understanding the complexity of the irregular migration process. This comes against the backdrop of the recent increase in irregular flows, the populist anti-migration rhetoric, human/labor rights concerns (e.g. Andall, 2007), and controversy surrounding the supposed negative impact of irregular migration 
on some non-unionized blue-collar workers in host countries (e.g. Refslund and Thörnquist, 2016). Irregular migration has been examined from a broad perspective in the literature. A large part focuses on the impact that such migration has on host countries, while a smaller part focuses on identifying factors pushing people to opt for irregular migration... The relative thinness of this strand can be attributed to the lack of adequate data on the determinants of irregular migration, which impedes research on the subject matter (Bratsberg, 1995). ${ }^{3}$ In this respect, an important aspect of developing the literature on irregular migration is the empirical investigation of the drivers of such flows in home countries.

The decision to emigrate relates to a benefit-cost analysis that accounts for economic and social conditions of the individual in addition for the legal context in the host and origin country (Ryo, 2013). Given that the legal context matters, irregular migration can be seen as a special form of labor migration (Vickstrom, 2014). According to Chiswick (1978), immigrants earn less than natives do when they join the labor market, which raises a number of questions on the earning abilities of irregular migrants who have less agency than regulars do. For instance, irregular migrants face discrimination based on ethnicity (Muñoz de Bustillo and Antón, 2010). SabatesWheeler et al. (2008) argue that employees are more likely to take the regular path of emigration compared to unemployed individuals. In addition, irregular migrants are more price sensitive to the migration cost than their regular counterparts are. Paradoxically, Mbaye (2014) argues that enhanced migration controls actually deter regular instead of irregular migration. For example, irregular migrants have a higher propensity to take risks, including the risk of death, when crossing seas and land borders. These controls may have the perverse effect of promoting the irregular channel. However, as the cost of irregular migration becomes excessive for both the potential migrant and employer, this perverse effect is mitigated (Calavita, 2006). Reyneri (1998) and De Haas (2009) find that constraints to regular migration in host countries promote irregular migration from North Africa. Loschmann et al. (2014) argue that contrary to regular migration, irregular migration is driven by the absence of possibility to migrate formally. Jahn and Straubhaar (1998) note that legal restrictions to enter the host country is the most important factor shaping irregular migration. In other words, entry regulation defines the 'irregularity' in

\footnotetext{
${ }^{3}$ Such studies have been also conducted by host countries governments. For instance, the Department of Immigration and Border Protection in Australia conducted a study in 2014 to examine the determinants of irregular migration from Afghanistan (Loschmann et al., 2014).
} 
the migration process. Finally, Pena (2010) examines the relationship between wage contracts, legal status, and poverty among US farm workers. Results indicate that irregular migrants are more likely to work in piece-rate arrangements and to be poor.

Empirical studies focus on both microeconomic and macroeconomic determinants of migration (Massey et al., 1999). Ryo (2013) proposes a model of irregular migration in which the decision to irregularly migrate is a function of national, community and household contexts (macro level) on one hand, and rational choice benefit-cost calculation coupled with norms at the individual (micro) level on the other hand. Both levels shape the decision to migrate irregularly. Put differently, the macroeconomic context affects the availability or lack of economic opportunities, which are further constrained by the lack of economic freedoms and weak public institutions (Gwartney et al., 2014), limited possibility for productive entrepreneurship (Meierrieks and Renner, 2017) and fiscal austerity measures in the home country (Juska and Woolfson, 2015). Whereas economic incentives and constraints reflected by cost-benefit analyses can explain what pushes individuals to migrate (Massey et al., 1994), the main push incentives relate to individual welfare enhancement from emigration, typically in terms of income differential between home and host countries subject to a travel cost constraint (Bauer and Zimmermann, 1998) and expected cost of detention and risk of physical injury (Buehn and Eichler, 2013). Besides these factors, a number of studies focus on non-economic drivers of migration such as trust and authority, and perceptions about labor markets and opportunities. According to Ryo (2013), these non-economic factors can be summarized into three categories: morality, legitimacy, and social norms.

The labor migration literature devotes much attention to both economic and labor market conditions. Economic conditions of people and different constraints they face in their life play a role in the decision to migrate irregularly. The expected utility from leaving the home country usually depends on the economic condition in both home and host countries (Entorf, 2002). Economic theory argues that people tend to emigrate when the expected economic opportunities in the host country could improve their wealth (e.g. Buehna and Eichlerb, 2013). Browne (2015) finds that the lack of economic opportunities in the home country strongly affects the decision to illegally migrate. Using evidence from Morocco, Cherti and Grant (2013) find that less wealthy individuals are less likely to migrate regularly and more likely to do so irregularly. Reitano et al. (2014) reports that wealth inequality increases the desirability to engage in illegal migration by 
the poor. The lack of financial assets in home countries constitutes an important motive for irregular migrants coming into Europe rather the economic prospects in the potential host country (Kuschminder et al., 2015). El Mahdi (2013) also finds evidence that economic constraints are major drivers of emigration amongst Egyptian youth. Moreover, the need to overcome these constraints via remittances drives both regular and irregular migration decisions (Kahn et al., 2014).

Additionally, labor market conditions matter when examining the path of irregular migration. Evidence shows that $27 \%$ of irregular migrants from Afghanistan are unemployed and come from lower socio-economic strata using data for 2011 (Loschmann et al., 2014). They find, using a probit model, that being unemployed increases the likelihood to engage in irregular migration both before and after the 2001 regime change in Afghanistan. They also find that individuals from low socio-economic standing with no education or work experience are more likely to express the need to migrate irregularly. In North America, Buehna and Eichlerb (2013) show that work conditions in the US combined with deteriorating work opportunities (high unemployment rates and low real wages) in Mexico are among the main drivers of irregular Mexican migrant flows into the US. As a corollary, they find that a lower unemployment rate and a higher expected wage in Mexico make people less likely to emigrate illegally. Ryo (2013) corroborates these results on employment and finds that economic incentives dominate the potential risk for illegal migration from Mexico to the US. Moreover, Abdel-karim (2016) investigates the determinants of irregular migration from North Africa to Southern Europe using a logit model based on survey data conducted in 1998. She finds that education and employment correlate positively with legal migration.

A number of insights from the industrial relations literature can also provide further understanding of the determinants of irregular migration. For instance, our calculations based on data drawn from the SAHWA Youth Survey (2016) indicate that most of the youth in MENA countries state that the lack of professional opportunities (unemployment or underemployment) is the number one reason to emigrate. This fact suggests that studying the determinants of irregular migration can also be related to work place specific characteristics such as type of contracts and social coverage, social networks, and institutional arrangements. Social network arrangements are those that are related to the propensity of the migrant of taking calculated risks based on either information about the host country or on the existence of a network that might 
smooth the migratory transition. For example, Mbaye (2014) finds that people having friends and relative living abroad have higher propensity to migrate irregularly from Senegal. Expectations from "trusted social networks" about living conditions in potential host countries shape the decision to emigrate (Browne, 2015). Van Dalen et al. (2005) find that the network effects for regular migration were important in Egypt and Ghana but not in Morocco and Senegal. Huber and Nowotny (2016) find evidence that the migratory duration is reduced by previous mobility experience. Furthermore, D’Isanto et al. (2016) find that being abroad, measured in months, increases the probability of migrating irregularly to Italy. ${ }^{4}$

Institutional settings in the home country and the level of democracy may also have a bearing on the propensity to migrate in general and to illegally do so in particular, since it relates to the level of trust an individual have in the home and host institutions and their ability to prevent entry or prosecute the irregular migrant. For instance, Browne (2015) argues that institutional factors such as "corruption, weak border control, and easy access to smugglers" may facilitate irregular migration. El Mehdi (2013) emphasizes the role of weak institutions in Egypt and Morocco as an impetus for irregular migration, while Wright (2012) indicates that host countries with more relaxed migration policies are more likely to have industries that are receptive to migrant labor. Moreover, institutions in both home and host countries encourage the irregular aspect of migration by promoting the free movement of goods and knowledge while restricting labor movement across borders (Donato and Massey, 2016; Vickstrom, 2014).

The above survey of the literature clearly indicates that the empirical evidence on the determinants of irregular migration is a growing, strand in the migration literature (Costantino, 2016). More importantly, while others have explored the issue for other age groups (e.g. Park and Kim, 2015), evidence on youth is limited.

\footnotetext{
${ }^{4}$ In our paper, we capture these adaptability and mobility factors by controlling for three variables, which are membership in a political party, living in the same place of birth, and travel abroad during the youth's lifetime. We use these variables as a proxy for adaptability and mobility since they capture the youths' social and informational networks at home and abroad. Indeed, capturing the membership in a political party is of great importance in MENA countries since the Arab Spring demonstrations were driven by the youth.
} 


\section{Methodology}

\subsection{Data and variables}

We use a micro-level data taken from the SAHWA Youth Survey (2016). This survey is a unique and rich multi-country survey conducted by the SAHWA Project ${ }^{5}$ covering five major MENA countries: Lebanon, Egypt, Tunisia, Algeria, and Morocco. The survey randomly sampled 9,860 Arab youth respondents and was designed to be nationally representative of youth aged 15 to 29 years in each of the five countries. Our final regression sample includes 2,762 observations after excluding responses with missing values. The questionnaires cover the following themes: education, employment, labor markets, social exclusion, political engagement, culture and values, gender issues, migration and international mobility, and institutional issues. ${ }^{6}$

In order to study the factors affecting the decision of MENA youth to engage in irregular emigration, we define the dependent variable to be equal to one if the youth indicated a willingness to irregularly migrate, and equal to zero otherwise.

We control for a number of explanatory variables related to youth observable characteristics. These characteristics relate to socio-economic factors, economic constraints, mobility and adaptability factors, labor market factors, institutional factors, and Arab Spring indicators. First, socio-economic characteristics include a binary variable for male, age in years, a binary variable for marriage, two binary variables for school and university education, and finally a binary variable for vocational training. Second, wealth factors include the variable called "roominess" of the dwelling, which we define as the ratio of the number of rooms to the number of inhabitants in the household. We also use financial support from parents and association with the upper social class as binary variables. All three variables capture scarcity and socio-economic constraints. Third, mobility and adaptability factors include three binary variables for membership in a political party, living in the same place of birth, and for travel abroad during the youth's lifetime. Fourth, labor market factors include a list of binary variables for

\footnotetext{
${ }^{5}$ The SAHWA Project (www.sahwa.eu) is an interdisciplinary cooperative research project led by the Barcelona Centre for International Affairs (CIDOB) and funded by the European Commission. It brings together fifteen partners from Europe and Southern and Eastern Mediterranean countries to research youth prospects and perspectives in a context of multiple social, economic and political transitions in five Arab countries (Morocco, Algeria, Tunisia, Egypt and Lebanon).

${ }^{6}$ It should be noted that the SAHWA Youth Survey (2016) is currently made available only to members of the SAHWA consortium and will made available to the public in April 2018.
} 
unemployment, availability to work in less than two weeks, private sector employment, social security system coverage, and type of work contract. Fifth, institutional factors cover four binary variables where the category one in each variable indicates that the youth respondent has no confidence in the legal system, no confidence in the European Union, no confidence in elections, and belief in democracy, respectively. Finally, our explanatory variables include two indictors of economic and political exclusion that allows us to consider the effect of the salient features of the Arab Spring (2011) on the decision to engage in irregular migration. Economic exclusion (pre/post- Arab Spring) is captured by a binary variable indicating whether the economy is/was "in good shape and everybody can live decently". While, political exclusion is captured by a binary variable indicating whether individuals can "live without fear of being illegally arrested”.

\subsection{Sample characteristics}

Table 1 presents the summary statistics for the full sample of the variables used in our empirical investigation. We observe that $19 \%$ of youth want to emigrate irregularly from the MENA countries under consideration. Social economic characteristics show that $54 \%$ youth respondents are male, while the average sample age is 22 years. Moreover, around 23\% of the respondents are married. The majority have school education as the highest attainment (69\%) followed by university education (27\%). Interestingly, only $7 \%$ of all youth respondents have received vocational training. Economic constraint factors indicate that on average there are 0.9 rooms available per inhabitant in the dwelling where the youth respondent resides. In addition, 57\% of youth receive financial support from parents, while $29 \%$ of youth belong to the upper social class. Interestingly, there seems to be evidence of lack of youth mobility since only $3 \%$ of respondents have been abroad, while $80 \%$ still live in the same place as their birthplace. Labor markets factors show that $29 \%$ of respondents are unemployed, which is in agreement with the official statistics on the MENA region that indicate that youth unemployment was 30\% in 2015 (ILO, 2015). Moreover, 26\% of those who work are in the private sector, while only $10 \%$ of the workers are insured by a national social security system. Institutional factors indicate that $22 \%$ of youth respondents have no confidence in the legal system, while 39\% and 31\% of these respondents report no confidence in the European Union and local elections respectively. The results also show that $75 \%$ of youth believe in democracy. Finally, Arab Spring indicators indicate that the perception of economic exclusion has decreased while that of political exclusion has only minimally increased in the post-Arab Spring period. 


\section{[Insert Table 1 here]}

Table 2 shows the percentage of youth reporting their willingness to migrate irregularly by characteristic. The results show that $83 \%$ of male report a willingness to migrate irregularly, while only $9 \%$ of married have an intention to migrate irregularly. We observe that $80 \%$ of those pro-irregular migration have a school education, while around $17 \%$ of the youth who report a willingness to irregularly emigrate have a university education and received vocational training. We also find that 39\% of those respondents received financial support from parents and around $20 \%$ of them belong to the upper social class, while only $7 \%$ of youth who report a willingness to irregularly emigrate have been abroad. The data show that around $46 \%$ of youth willing to irregularly migrate are unemployed, while $36 \%$ of them work in the private sector, and only $6 \%$ of them are covered by a national social security system. We observe that around 33\% of youth willing to irregularly migrate have no confidence in the legal system, while $72 \%$ of them believe in democracy. We find that around $16 \%$ of the youth who report a willingness to irregularly emigrate are coming from Lebanon, 5\% are from Egypt, 17\% are from Tunisia, 27\% are from Algeria, and 36\% are from Morocco. Finally, we observe that $70 \%$ of youth who report a willingness to migrate live in urban areas.

[Insert Table 2 here]

\subsection{Modeling approach}

The modeling approach follows a standard discrete choice model. We use a probit model in order to examine the implications of different explanatory variables on the probability to emigrate irregularly:

$I_{2}$ MIGRATE $_{i}=$ Socio $_{i} \beta_{1}+$ Wealth $_{i} \beta_{2}+$ Mobility $_{i} \beta_{3}+$ Labor $_{i} \beta_{4}+$ Institution $_{i} \beta_{5}+$ ArabSpring $_{i} \beta_{6}+u_{i}$

where $I R R \_$MIGRATE $E_{i}$ is the dependent variable defined as a binary variable equals to one if youth $i(i=1, \ldots, I)$ expresses a likelihood to emigrate irregularly and zero otherwise. The explanatory variables are the socio-economic factors (Socio), wealth factors (Wealth), mobility and adaptability factors (Mobility), labor market factors (Labor), Institutional factors (Institution), Arab Spring factors (ArabSpring), and $u_{i}$ is defined as the error term, which follows a normal distribution. The error terms are clustered by country in order to improve the 
efficiency of the standard errors. Finally, $\beta_{i}$ are vectors of the parameters to be estimated. Since we use a probit model, we estimate first the probability of youth to irregularly emigrate, then we generate the marginal effects to provide the sign and magnitude of change in intentions to irregularly emigrate following a change in the explanatory variables.

We run eight different regression models in order to take into account the contribution of each category of explanatory variables. In model 1, we run a probit model controlling only for factors that strongly correlate with wealth (roominess, financial support from parents, and upper social class). Model 2 adds mobility and adaptability factors (belong to political party, living in same place where born, and been abroad). Model 3 adds the unemployment variable, while model 4 considers the same variable but with control for institutional factors (No confidence in the legal system, no confidence in the European Union, no confidence in elections, belief in democracy). Next, in model 5 we replace the unemployment variable with a dummy variable indicating whether the youth is available to work. In model 6, we consider other labor market factors (working in the private sector and job insured by the social security system), while model 7 has the same specification as model 6 but with the addition of institutional factors. The final model adds to model 7, the type of contract (indefinite and fixed term) in addition to two variables on economic and political exclusion pre- and post-Arab Spring. All eight models control for a set of socio-economic variables that include gender, age, marital status, vocational training, and education.

\section{Results}

The estimated marginal effects of the probit model are presented in Table 3.

[Insert Table 3 here]

Beginning with model 1, that controls only for wealth factors, we observe that the variables roominess, financial support received from parents, and being part of the upper social class are all negatively and significantly correlated with the probability to engage in irregular migration. These results are robust across all eight models (column 2 through 8). This indicates that there is a strong evidence that an increase in the youth's wealth acts as a deterrent against irregular migration. 
In model 2 that adds mobility and adaptability controls, we find that belonging to a political party increases the probability to migrate irregularly, while living in the same place as the birthplace leads to a lower probability to migrate. Moreover, the youth, reporting to have been abroad, show significant inclination to migrate irregularly. When running the full model in column 8, we find that the first variable's marginal effect remains positive and statistically significant, while the second loses its significance. The being abroad variable becomes, however, statistically significant. Taken together these results suggest that youth who are able to adapt locally as part of a political movement and those who visited a foreign country are more likely to report a willingness to migrate.

Model 3 adds the unemployment status of youth. We find that being unemployed increases the probability of wanting to irregularly-migrate by 13 percentage points. This probability remains the same when we control for institutional factors in model 4. This result is in line with recent evidence from the MENA region indicating that being unemployed increases significantly the willingness to emigrate (Dibeh et al., 2017).

Model 5 removes the unemployment status and replaces it with a variable indicating whether the youth is available to work. By contrast, the results reveal that youth that are available to work within two weeks are less likely to migrate irregularly by around 6 percentage points.

Continuing with labor market drivers, Models 6, 7, and 8 show that being-employed in the private sector reduces the likelihood to engage in irregular migration by an average of 7.5 percentage points compared with those working in the public sector. Interestingly, youth that are covered by the national social security scheme are also found to be less likely to irregularlymigrate by an average of 10 percentage points compared with those with no social security scheme. In the full model (model 8), we add the type of contract and find that youth with indefinite or fixed term contracts are less likely to migrate by 2 and 5 percentage points, respectively, compared with those with a verbal or no work contract.

Given that MENA countries witnessed important political transitions over the past six years, it is of importance to investigate the effect of the quality of public institutions on migration. Our results indicate that youth are more likely to migrate irregularly when they have no confidence in the legal system in the home country (models 4, 5, 7, and 8). Moreover, we find that they are less likely to migrate when they report to have a belief in the democratic ideal in their home country. 
In contrast, lack of confidence in the European Union reduces the probability to migrate irregularly (columns 7 and 8). Lastly, "no confidence" in elections has no bearing on the probability to migrate.

Finally, our dataset allows controlling for two variables of interest that can be seen as a proxy for Arab Spring indicators. We find that the perception of economic exclusion in the post-Arab Spring era has increased significantly the willingness to migrate irregularly, while this factor was not important in the pre-Arab Spring era (models 4, 5, 7, and 8). By contrast, the perception of political exclusion in the post-Arab Spring era has decreased the willingness to migrate irregularly, which was not the case in the pre-Arab Spring era.

\section{Discussion}

The results presented above lend support to the existing studies on the determinants of irregular migration. We can draw a number of lessons from our empirical investigation.

First, facing lower economic constraints leads to a lower propensity of youth migration because of a higher opportunity cost of leaving the home country. This finding reinforces the qualitative studies of Cherti and Grant (2013) and Browne (2015) on a number of MENA countries. As a corollary, higher wealth inequality can be seen as a migration-promoting factor for those youth in the bottom of the wealth distribution.

Second, youth who experience a certain extent of mobility and adaptability are more likely to express a willingness to migrate irregularly. This finding is in line with D’ Isanto et al. (2016). A plausible explanation is that these youths have overcome a number of barriers, which make them more open to risk taking such as the perils associated with irregular migration. The finding can also be related with some evidence from the MENA region showing that people with networks abroad are more likely to migrate (Van Dalen et al., 2005).

Third, as discussed above, unemployed youth are more likely to want to migrate irregularly in line with the results from Afghanistan (Loschmann et al., 2014); from Mexico (Buehna and Eichlerb, 2013) for the case of irregular migration; and from Germany for the case of regular migrants (Windzio, 2004). The fact that the youth unemployment rate in the MENA region is the higher than other economic regions (ILO, 2015), indicates that migration in general and irregular migration in particular act as a coping mechanism for the dismal reality of MENA labor markets. 
It is also worth mentioning that the relationship between unemployment and migration is of great importance for host countries where migration policies are sensitive to the unemployment rate (Hazari and Sgro, 2000; Carraro and Soubeyran, 2005). The effect of unemployment on irregular migration can be linked to the wider employment literature showing that the unemployed are more likely to relocate (Fendel, 2014) and are more sensitive to other economics factors discussed in this paper affecting the probability to emigrate (DaVanzo, 1978).

Fourth, the results related to being employed in the private sector and being covered by social security suggest that labor market formality acts as firewall against irregular migration since a worker in the formal private sector enjoys higher salaries and job security compared with their peers in the informal sector (Meghir et al., 2015). This latter result should be interpreted with caution given the fact that social security covers only a small proportion of workers in the formal sector in developing countries to which the MENA region belongs (Jung and Tran, 2012). Along the same line, results on contract type may indicate that job stability increases wages (Card and De La Rica, 2005) and thus acts as a deterrent against irregular migration (Caparrós Ruiz, 2014). It is commonly documented in labor studies that the types of contracts (fixed-term or indefinite) influence wage growth and labor mobility. This evidence can be linked to our results indicating that having a permanent position reduces labor mobility and thus the probability to migrate (Amuedo-Dorantes and Serrano-Padial, 2007).

Finally, when assessing how public governance affects irregular migration we find contrasting evidence between the home and host country. Perceptions of poor governance in the home country acts as a push factor, while good governance in the host country acts as pull factor. Although, it might still be early to assess the full implications of the Arab Spring on migration, our results indicate that both economic and political exclusions are relevant factors despite the fact that in the post-Arab Spring era the salience of these exclusions has changed. In this respect, it is recognized that economically and politically exclusive economic systems can lead to instability such as the transitions that occurred during the Arab Spring (Robinson and Acemoglu, 2012). 


\section{Conclusion}

Based on a unique and new dataset covering the youth population in five major MENA countries, this paper examined the effect of different features of the labor market and institutions on irregular migration which is a form of international migration subject to much controversy in political and policy circles across the Mediterranean basin. The results of this paper also add to the growing literature on migratory choice of individuals from the MENA region (e.g. Dibeh et al., 2017) and to the broader literature on irregular migration documenting the push effect of less favorable social and economic conditions in home countries (Entorf, 2002). The paper also provides empirical results that can be of used by policy-makers by providing them with quantifiable measures of the weaknesses of labor markets for youth in the MENA region and their respective impact on their willingness to migrate irregularly.

Specifically, the results of our paper demonstrate that: (1) labor market drivers (unemployment, job sector, social security, contract type) are of great importance for the decision to migrate irregularly; youth working in the private sector, covered by a national social security scheme, and having job stability have lower propensity to irregularly migrate. (2) The quality of institutions does matter, but it shows some mixed results. (3) Arab Spring indicators show that economic and political exclusion have significant effects on the decision of youth to emigrate before and after the Arab Spring in 2011. Lastly, (4) youth with higher wealth are less likely to engage in irregular migration. That is, our results shed new light on irregular emigration from conflict areas that is driven by a complex combination of social, economic, and political drivers. This is the case because our results identify a rich set of variables related to labor market and institutional settings that reflect this complex interaction.

Finally, it is worth mentioning that the countries in our study did not witness civil wars in the aftermath of the Arab Spring and therefore, security was not the dominant factor. This feature allowed us to elucidate the effect of the socio-economic, labor market, and institutional factors that shape the decision to migrate irregularly in these countries. For future work, hedonic factors related to the decision to migrate might be worth exploring when data becomes available. For instance, people who went through irregular migration have reported an increase in their subjective well-being and level of happiness in the host country (D'Isanto et al., 2016). Another 
possible extension will be feasible when panel data becomes available, which would allow us to take into account the dynamic behavior of irregular migrants across time in the MENA region. 


\section{References}

Abdel-karim, A. H. (2016). Determinants of illegal migration from North Africa to Southern Europe. Migration Letters, 13(3), 455.

Amuedo-Dorantes, C., \& De la Rica, S. (2007). Labour market assimilation of recent immigrants in Spain. British Journal of Industrial Relations, 45(2), 257-284.

Amuedo-Dorantes, C., \& Serrano-Padial, R. (2007). Wage growth implications of fixed-term employment: An analysis by contract duration and job mobility. Labour Economics, 14(5), 829847.

Andall, J. (2007). Industrial districts and migrant labour in Italy. British journal of industrial relations, 45(2), 285-308.

Baldwin-Edwards, M. (2008). Towards a Theory of Illegal Migration: historical and structural components. Third World Quarterly, 29(7), 1449-1459.

Bauer, T., \& Zimmermann, K. F. (1998). Causes of international migration: a survey. Crossing borders: regional and urban perspectives on international migration, 95-127.

Borodak, D., \& Tichit, A. (2014). Should we stay or should we go? Irregular migration and duration of stay: the case of Moldovan migrants. Migration Studies, 2(3), 415-447.

Bratsberg, B. (1995). Legal versus illegal US immigration and source country characteristics. Southern economic journal, 715-727.

Browne, E. (2015). Drivers of irregular migration in North Africa. GSDRC Helpdesk Research Report 1271.

Buehn, A., \& Eichler, S. (2013). Determinants of Illegal Mexican Immigration into the US Southern Border States. Eastern Economic Journal, 39(4), 464-492.

Calavita, K. (2006). The Immigration Conundrum in Italy and Spain. Insights on Law and Society, 7(2), 7 .

Caparrós Ruiz, A. (2014). Wage inequality of immigrants by type of contract in Spain. International Journal of Manpower, 35(6), 817-833.

Card, D., \& De La Rica, S. (2005). The effect of firm-level contracts on the structure of wages: evidence from matched employer-employee data (No. w11829). National Bureau of Economic Research.

Carraro, C., \& Soubeyran, A. (2005). Labour demand with heterogeneous workers: Migrations and unemployment. Research in Economics, 59(2), 119-136. 
Cherti, M., \& Grant, P. (2013). The myth of transit: Sub-Saharan migration in Morocco. Institute for Public Policy Research, London, June.

Chiswick, B. (1978). 'The effect of Americanization on the earnings of foreign-born men'. Journal of Political Economy, 86: 897-921.

Costantino, F. (2016). Irregular Immigration, Labour Market and Enforcement at the US-Mexico Border. Evidence from a Time-Series Analysis (1963-2014). International Migration, 54(3), 125-138.

DaVanzo, J. (1978). Does unemployment affect migration? Evidence from micro data. The Review of Economics and Statistics, 504-514.

De Bruycker, P., Di Bartolomeo, A., \& Fargues, P. (2013). Migrants smuggled by sea to the EU: facts, laws and policy options. Migration Policy Centre, MPC Research Report 2013/09.

De Haas, H. (2008). "Irregular migration from West Africa to the Maghreb and the European Union: An overview of recent trends" (No. 32). Geneva: International Organization for Migration.

De Haas, H. (2009). Morocco: Migration profile. Focus-Migration 16: 1-11.

Dibeh, G., Fakih, A., \& Marrouch, W. (2017). Decision to Emigrate Amongst the Youth in Lebanon, International Migration, forthcoming.

D’Isanto, F., Fouskas, P., \& Verde, M. (2016). Determinants of well-being among legal and illegal immigrants: Evidence from South Italy. Social Indicators Research, 126(3), 1109-1141.

Donato, K. M., \& Massey, D. S. (2016). Twenty-First-Century Globalization and Illegal Migration. The ANNALS of the American Academy of Political and Social Science, 666(1), 726.

Dustmann, C., Fasani, F., Frattini, T., Minale, L., \& Schönberg, U. (2016). On the Economics and Politics of Refugee Migration, IZA Working Paper No. 10234.

El Mahdi, A. (2014). Migration from South Mediterranean countries to EU: Economic Aspects. EuroMed, Information and Training Seminars for Diplomats. [Date accessed 17.5.2017] http://www.euromedtraining.eu/fichiers/seminar3/pedago/7_EN.pdf

Entorf, H. (2002). Rational Migration Policy Should Tolerate Non-zero Illegal Migration Flows: Lessons from Modelling the Market for Illegal Migration. International Migration, 40(1), 27-43.

Fargues, P. (2009). Work, refuge, transit: an emerging pattern of irregular immigration South and East of the Mediterranean. International migration review, 43(3), 544-577. 
Fendel, T. (2014). Work-related migration and unemployment. Journal for Labour Market Research, 47(3), 233-243.

Gwartney JD, Lawson RA, Hall J (2014) Economic Freedom of the World: 2014 Annual Report. The Fraser Institute, Vancouver.

Hammond, T. G. (2015). The Mediterranean migration crisis. Foreign Policy Journal.

Hazari, B. R., \& Sgro, P. M. (2000). Wage indexation, migration, and unemployment. International Review of Economics \& Finance, 9(3), 257-265.

Huber, P., \& Nowotny, K. (2016). The Impact of Relative Deprivation on Return Intentions Among Potential Migrants and Commuters. Journal of Regional Science, 56(3), 471-493.

International Labour Organization (ILO) (2015). Global Employment Trends for Youth 2015: Scaling up investments in decent jobs for youth. International Labour Office - Geneva: ILO, 2015, (on-line) [Date accessed 17.4.2017] www.ilo.org/wcmsp5/groups/public/--.../WCms_412015.pdf

Jahn, A., \& Straubhaar, T. (1998). A survey of the economics of illegal migration. South European Society and Politics, 3(3), 16-42.

Jung, J., \& Tran, C. (2012). The extension of social security coverage in developing countries. Journal of Development Economics, 99(2), 439-458.

Juska, A., \& Woolfson, C. (2015). Austerity, labour market segmentation and emigration: the case of Lithuania. Industrial Relations Journal, 46(3), 236-253.

Kahn, Y., Dumas, A., Eshet, Y., \& Billfeld, N. (2014). Migration and Subjective Poverty in sending countries: An analysis of the Egyptian case. Migration Letters, 11(3), 353.

Koser, K., \& McAuliffe, M. (2013). Establishing an Evidence-Base for Future Policy Development on Irregular Migration to Australia. Irregular Migration Research Program Occasional Paper Series, Department of Immigration and Citizenship.

Kuschminder, K., de Bresser, J., \& Siegel, M. (2015). Irregular migration routes to Europe and factors influencing migrants' destination choices. Maastricht: Maastricht Graduate School of Governance.

Loschmann, C., Kuschminder, K., \& Siegel, M. (2014). The root causes of movement: Exploring the determinants of Irregular Migration from Afghanistan. Irregular Migration Research Program Occasional Paper Series, Department of Immigration and Citizenship.

Mangin, S., \& Zenou, Y. (2016). Illegal migration and policy enforcement. Economics Letters, 148, 83-86. 
Massey, D. S., Arango, J., Hugo, G., Kouaouci, A., Pellegrino, A., \& Taylor, J. E. (1994). An evaluation of international migration theory: The North American case. Population and development Review, 699-751.

Massey, D. S., Arango, J., Hugo, G., Kouaouci, A., \& Pellegrino, A. (1999). Worlds in Motion: Understanding International Migration at the End of the Millennium: Understanding International Migration at the End of the Millennium. Clarendon Press.

Mbaye, L. M. (2014). “Barcelona or die”: understanding illegal migration from Senegal. IZA Journal of Migration, 3(1), 21.

Meghir, C., Renata N., \& Robin. J-M. (2015). Wages and Informality in Developing Countries. American Economic Review, 105(4), 1509-46.

Mehdi, A., \& Fares, M. L. (2004). Globalization, migration and the Arab world. International Organization of Migration.

Muñoz de Bustillo, R., \& Antón, J. I. (2010). From sending to host societies: immigration in Greece, Ireland and Spain in the 21st century. Industrial Relations Journal, 41(6), 563-583.

Orrenius, P. M., \& Zavodny, M. (2016). Irregular immigration in the European Union, Swedish Institute for European Policy Studies.

Park, J., \& Kim, K. (2015). Internal migration of the elderly in Korea: A multilevel logit analysis of their migration decision. Asian and Pacific Migration Journal, 24(2), 187-212.

Pena, A. A. (2010). Poverty, legal status, and pay basis: The case of US agriculture. Industrial Relations: A Journal of Economy and Society, 49(3), 429-456.

Reitano, T., Adal, L. \& Shaw, M. (2014). Smuggled Futures: The dangerous path of the migrant from Africa to Europe. Global Initiative against Transnational Organized Crime.

Refslund, B., \& Thörnquist, A. (2016). Intra-European labour migration and low-wage competition-comparing the Danish and Swedish experiences across three sectors. Industrial Relations Journal, 47(1), 62-78.

Renner, L., \& Meierrieks, D. (2016). Stymied Ambition: Does a Lack of Economic Freedom Lead to Migration? Journal of Population Economics, 30(3), 977-1005.

Reyneri, E. (1998). The role of the underground economy in irregular migration to Italy: cause or effect?. Journal of Ethnic and Migration Studies, 24(2), 313-331.

Robinson, A. D., \& Acemoglu, R. (2012). Why nations fail. The Origins of Power, Prosperity and Poverty, Nueva York. 
Ryo, E. (2013). Deciding to cross: norms and economics of unauthorized migration. American Sociological Review, 78(4), 574-603.

Sabates-Wheeler, R., Sabates, R., \& Castaldo, A. (2008). Tackling poverty-migration linkages: evidence from Ghana and Egypt. Social Indicators Research, 87(2), 307-328.

Van Dalen, H. P., Groenewold, G., \& Schoorl, J. J. (2005). Out of Africa: what drives the pressure to emigrate?. Journal of Population Economics, 18(4), 741-778.

Vickstrom, E. (2014). Pathways into irregular status among Senegalese migrants in Europe. International Migration Review, 48(4), 1062-1099.

Windzio, M. (2004). Zwischen Nord-und Süddeutschland: Die Überwindung räumlicher Distanzen bei der Arbeitsmarktmobilität. Zeitschrift für ArbeitsmarktForschung-Journal for Labour Market Research, 37(1), 29-44.

Wright, C. F. (2012). Immigration policy and market institutions in liberal market economies. Industrial Relations Journal, 43(2), 110-136. 
Table 1: Summary statistics of variables

\begin{tabular}{lcc}
\hline & Mean & Standard Deviation \\
\hline Dependent variable: Irregular migration & 0.19 & 0.39 \\
Socio-economic factors & & \\
\hline Male & 0.54 & 0.50 \\
Age & 21.83 & 4.19 \\
Married & 0.23 & 0.42 \\
Education level: No education & 0.03 & 0.19 \\
Education level: School & 0.69 & 0.46 \\
Education level: University & 0.27 & 0.44 \\
Vocational training & 0.07 & 0.26 \\
& & \\
Wealth factors & & 0.51 \\
Roominess & 0.93 & 0.50 \\
Financial support from parents & 0.57 & 0.45 \\
Upper social class & 0.29 & \\
& & \\
Mobility and adaptability factors & & 0.28 \\
Belong to political party & 0.09 & 0.40 \\
Living in same place where born & 0.80 & \\
Been abroad & 0.03 &
\end{tabular}

Labor market factors

$\begin{array}{lll}\text { Unemployment } & 0.21 & 0.41 \\ \text { Availability to work in less than 2 weeks } & 0.70 & 0.46 \\ \text { Job sector: private } & 0.26 & 0.44 \\ \text { Job insured by the social security system } & 0.10 & 0.30 \\ \text { Type of contract: verbal } & 0.93 & 0.35 \\ \text { Type of contract: indefinite } & 0.04 & 0.21 \\ \text { Type of contract: fixed-term } & 0.03 & 0.17\end{array}$

Institutional factors

No confidence in the legal system $\quad 0.22 \quad 0.41$

No confidence in the European Union $\quad 0.39 \quad 0.49$

$\begin{array}{lll}\text { No confidence in elections } & 0.31 & 0.46\end{array}$

Belief in democracy $\quad 0.75 \quad 0.43$

Arab Spring factors

Economic exclusion: Post-Arab Spring $0.16 \quad 0.37$

Economic exclusion: Pre-Arab Spring $\quad 0.29 \quad 0.45$

Political exclusion: Post-Arab Spring $\quad 0.25 \quad 0.43$

Political exclusion: Pre-Arab Spring $0.23 \quad 0.42$

Number of observations 9860

Source: SAHWA Youth Survey (2016), author's analysis. 
Table 2: Percentage of youth reporting their willingness to migrate irregularly by characteristic Variable Percentage

Youth willing to migrate irregularly:

Is male

83.36

Is married

8.88

Has a school education

79.58

Has a university education

17.20

Received vocational training

17.58

Received financial support from parents

38.56

Belongs to the upper social class

20.42

Belongs to a political party

13.42

Lives in same place where born

81.66

Has been abroad

6.99

Is unemployed

45.56

Is available to work in less than 2 weeks

36.31

Works in the private sector

35.54

Is insured by the social security system $\quad 6.24$

Has an indefinite contract $\quad 2.84$

Has a fixed-term contract 2.46

Has no confidence in the legal system 33.27

Has no confidence in the European Union 31.19

Has no confidence in elections $\quad 40.26$

Believes in democracy $\quad 71.64$

Feels economically excluded: Post-Arab Spring 20.42

Feels economically excluded: Pre-Arab Spring 35.54

Feels politically excluded: Post-Arab Spring 30.43

Feels politically excluded: Pre-Arab Spring 24.20

Youth willing to migrate irregularly are from:

Lebanon

15.61

Egypt $\quad 4.50$

$\begin{array}{lr}\text { Tunisia } & 16.93\end{array}$

Algeria 27.21

Morocco 35.54

Youth willing to migrate irregularly are from:

Urban areas

70.13

Number of observations 9860

Source: SAHWA Youth Survey (2016), author's analysis. 
Table 3: Probit regression: The determinants of irregular migration coming out from the MENA countries (marginal effects)

\begin{tabular}{|c|c|c|c|c|c|c|c|c|}
\hline & (1) & (2) & (3) & (4) & (5) & (6) & (7) & $(8)$ \\
\hline Upper social class & $\begin{array}{c}-0.036^{* * *} \\
(0.001)\end{array}$ & $\begin{array}{c}-0.037 * * * \\
(0.001)\end{array}$ & $\begin{array}{c}-0.028^{* * *} \\
(0.000)\end{array}$ & $\begin{array}{c}-0.034 * * * \\
(0.001)\end{array}$ & $\begin{array}{l}-0.018 \\
(0.013)\end{array}$ & $\begin{array}{c}-0.033^{* * *} \\
(0.002)\end{array}$ & $\begin{array}{c}-0.037 * * * \\
(0.002)\end{array}$ & $\begin{array}{c}-0.036 * * * \\
(0.002)\end{array}$ \\
\hline Living in same place where born & & $\begin{array}{c}-0.004 * * * \\
(0.001)\end{array}$ & $\begin{array}{c}-0.006^{* * * *} \\
(0.000)\end{array}$ & $\begin{array}{c}-0.007^{*} \\
(0.004)\end{array}$ & $\begin{array}{l}-0.014 \\
(0.025)\end{array}$ & $\begin{array}{c}-0.001 * * \\
(0.001)\end{array}$ & $\begin{array}{l}-0.002 \\
(0.003)\end{array}$ & $\begin{array}{l}-0.001 \\
(0.004)\end{array}$ \\
\hline Been abroad & & $\begin{array}{c}0.026 \\
(0.026)\end{array}$ & $\begin{array}{c}0.02 \\
(0.021)\end{array}$ & $\begin{array}{l}0.025^{*} \\
(0.013)\end{array}$ & $\begin{array}{c}0.067 * * * \\
(0.005)\end{array}$ & $\begin{array}{c}0.023 \\
(0.022)\end{array}$ & $\begin{array}{l}0.026^{*} \\
(0.014)\end{array}$ & $\begin{array}{l}0.026^{*} \\
(0.014)\end{array}$ \\
\hline \multicolumn{9}{|l|}{ Labor market factors } \\
\hline Job sector: private & & & & & & $\begin{array}{c}-0.077^{* * *} \\
(0.001)\end{array}$ & $\begin{array}{c}-0.073^{* * *} \\
(0.001)\end{array}$ & $\begin{array}{c}-0.072^{* * * *} \\
(0.000)\end{array}$ \\
\hline Job insured by the social security system & & & & & & $\begin{array}{c}-0.109 * * * \\
(0.007)\end{array}$ & $\begin{array}{c}-0.108^{* * *} \\
(0.009)\end{array}$ & $\begin{array}{c}-0.094 * * * \\
(0.005)\end{array}$ \\
\hline Type of contract: indefinite & & & & & & & & $\begin{array}{c}-0.024 * * \\
(0.011)\end{array}$ \\
\hline Type of contract: fixed term & & & & & & & & $\begin{array}{c}-0.054^{* * *} \\
(0.018)\end{array}$ \\
\hline \multicolumn{9}{|l|}{ Institutional factors } \\
\hline No confidence in the legal system & & & & $\begin{array}{c}0.043 * * * \\
(0.012)\end{array}$ & $\begin{array}{c}0.039 * * * \\
(0.004)\end{array}$ & & $\begin{array}{c}0.050 * * * \\
(0.008)\end{array}$ & $\begin{array}{c}0.050^{* * *} \\
(0.008)\end{array}$ \\
\hline No confidence in the European Union & & & & $\begin{array}{l}-0.047 \\
(0.030)\end{array}$ & $\begin{array}{l}-0.022 \\
(0.029)\end{array}$ & & $\begin{array}{l}-0.051^{*} \\
(0.031)\end{array}$ & $\begin{array}{c}-0.051^{*} \\
(0.031)\end{array}$ \\
\hline
\end{tabular}


No confidence in elections

$\begin{array}{cccc}0.018 & -0.006 & 0.018 & 0.018 \\ (0.025) & (0.050) & (0.028) & (0.027) \\ -0.028 * * * & -0.027^{*} & -0.027 * * * & -0.027 * * * \\ (0.009) & (0.014) & (0.003) & (0.002)\end{array}$

Belief in democracy

$(0.014)$

$(0.003)$

$(0.002)$

Arab Spring factors

Economic exclusion: Post-Arab Spring

$0.039 * *$

$0.058^{* * *}$

$0.040 * * * \quad 0.040 * * *$

Economic exclusion: Pre-Arab Spring

$(0.002) \quad(0.004)$

$(0.004) \quad(0.003)$

Economic exclusion. Pre-Arab Spring

Political exclusion: Post-Arab Spring

$-0.006$

0.002

$-0.003$

$-0.003$

(0.006)

(0.009)

$(0.002)$

$(0.002)$

Political exclusion: Pre-Arab Spring

$-0.065 * * * \quad-0.088 * * *$

$-0.065 * * * \quad-0.064 * * *$

\begin{tabular}{lcccccccc} 
& & & & $(0.001)$ & $(0.015)$ & \multicolumn{2}{c}{$(0.001)$} & $(0.001)$ \\
\hline $\mathrm{N}$ & 2762 & 2762 & 2762 & 2762 & 2762 & 2762 & 2762 & 2762 \\
Pseudo R & 0.090 & 0.093 & 0.109 & 0.113 & 0.120 & 0.121 & 0.124 & 0.121 \\
Pseudo Log likelihood & -1223.303 & -1219.815 & -1198.703 & -1192.876 & -1183.589 & -733.136 & -1178.575 & -1182.780 \\
\hline
\end{tabular}

Source: SAHWA Youth Survey (2016), author’s analysis.

Notes: In all the regressions, we control for the socio-economic factors: male, age, married, vocational training, and two variables for education level (having a school and a university level) with no education category is the reference group for education variables. Statistical significance: $*=10 \%$; $* *=5 \%$; $* * *=1 \%$. No contract is the reference group for contract type variables. Robust and residence area clustered standard errors are in parentheses. 